\title{
ЕКОНОМІЧНЕ РЕГУЛЮВАННЯ ПРИРОДОКОРИСТУВАННЯ І ОХОРОНИ НАВКОЛИШНЬОГО ПРИРОДНОГО СЕРЕДОВИЩА
}

\author{
Гайворонська T.М., к.ю.н., доцент, \\ Глушенко Т.М., ст. викладач (УкрДУЗТ)
}

\begin{abstract}
В статті досліджено складові елементи економічного механізму забезпечення охорони навколишнього природного середовища. Визначено важливість управління охорони довкіллям $i$ природокористуванням на основі адміністративних методів. Зазначено необхідність тісного поєднання адміністративних і економічних методів у сфері природокористування. Розглянуто основні елементи, мету та особливості економічного механізму регулювання природокористування в Україні. Наведено основні елементи фінансового механізму екологічного призначення в розвинених країнах. Обтрунтовано необхідність удосконалення економіко-правових важелів природокористування і природоохоронної діяльності.

Ключові слова: економічні механізми, адміністративні методи, екологічна політика, навколиинє природне середовище, природоохоронна діяльність, природокористування.
\end{abstract}

\section{ЕКОНОМИЧЕСКОЕ РЕГУЛИРОВАНИЕ ПРИРОДОПОЛЬЗОВАНИЯ И ОХРАНЫ ОКРУЖАЮЩЕЙ ПРИРОДНОЙ СРЕДЫ}

\author{
Гайворонская Т.Н., к.ю.н., доцент, \\ Глушенко Т.Н., ст. преподаватель (УкрГУЖТ)
}

Рассмотрены составляюшие элементы экономического механизма обеспечения охрань окружающей природной среды. Определена важность управления охрань окружающей средой и природопользованием на основе административных методов. Указана необходимость тесного сочетания административных и экономических методов в сфере природопользования. Рассмотрены основные элементы, иели и особенности экономического механизма регулирования природопользования в Украине. Приведень основные элементы финансового механизма экологического назначения в развитых странах. Обоснована необходимость совершенствования экономико-правовых рычагов природопользования и природоохранной деятельности.

Ключевые слова: экономические механизмы, административные методы, экологическая политика, окружающую природную среду, природоохранная деятельность, природопользования.

(C) Гайворонська T.M., Глушенко Т.M.
Вісник економіки транспорту і промисловості № 60, 2017 


\title{
ECONOMIC REGULATION OF NATURAL RESOURCES MANAGEMENT AND ENVIRONMENTAL PROTECTION
}

\author{
Gaivoronskaya T.N., Ph.D., associate professor \\ Glushenko T.N., senior teacher (USURT)
}

The necessity of forming a new economic mechanism of nature management and financing of environmental measures in the conditions of formation market relations and processes of globalization as an organic component the system of management and regulation of the economy is determined. The constituent elements the economic mechanism of environmental protection are considered. The importance of environmental management and environmental management is determined on the basis of administrative methods. The necessity of a close combination of administrative and economic methods in the field of nature management is indicated. The main elements, goals and features of the economic mechanism of regulation of nature management in Ukraine are considered. The main elements of the financial mechanism of ecological use in the developed countries are presented. The necessity of improving the economic and legal levers of nature management and nature protection activities, which should take into account the properties of natural objects of the state, is substantiated.

Key words: economic mechanisms, administrative methods, environmental policy, environment, nature protection activity, nature management.

\begin{abstract}
Постановка
Необхідність

природокористуванням визначається як

різким погіршенням екологічної ситуації, кризовим станом природного середовища, так і закономірними тенденціями підвищення темпів розвитку сучасного суспільства. Нині природне середовище як найважливіший природний фактор виробництва i повноцінного життя суспільства потребує 3 боку держави всебічного захисту та охорони від загрозливої деградації та забруднення. Так, вкрай необхідними э питання формування дієвого механізму економічного
\end{abstract} регулювання природокористування 3 урахуванням найкращих світових практик.

Аналіз останніх досліджень i публікацій. Розробці теоретичних та прикладних питань природоохоронної діяльності присвячені наукові праці багатьох вчених-економістів. Варто зазначити роботи І.Я. Аксьонова, I.K. Бистрякова, B.I. Борейко, Б.В. Буркінського, П.П. Борщевського, Б.М. Данилишина, С.I. Дорогунцова, О.Л. Кашенко, М.М.Коржнева [7],
Н.В. Пахомової, В.Ф. Протасова, М.Ф. Реймерса, M.I. Фащевського, Т.С. Хачатурова, М.А.Хвесика [6]. Серед вчених, які працюють у напрямку вивчення елементів економічного механізму регулювання природокористування, можна виділити наукові роботи О. Васюти [5], О. Веклича, В. Бугаса [4], В. Голяна.

Проте наукові розробки у більшості випадків присвячені загальній характеристиці впливу господарської діяльності на навколишнє природне середовище. Проте, недостатньо дослідженими є існуючі в Україні методи регулювання природокористування. Тож, актуальним i вкрай необхідним $\epsilon$ удосконалення підходів до вирішення не лише економічних, соціальних, а й екологічних проблем сучасного суспільства, як запоруки сталого розвитку економіки країни.

\begin{tabular}{lrrr}
\multicolumn{1}{c}{ Саме } & тому & \multicolumn{1}{c}{ метою } & \multicolumn{1}{c}{ статті $\mathbf{c}$} \\
дослідження & нині & діючого & механізму \\
економічного & & регулювання \\
природокористування & i & охорони \\
навколишнього природного середовища, та \\
визначення & \multicolumn{2}{c}{ основних } & напрямів
\end{tabular}


удосконалення економічного регулювання і впровадження найкращих надбань світових теорій і практик природокористування.

Виклад основного матеріалу дослідження. Розвиток суспільства на сучасному етапі вкрай вимагає вироблення збалансованого підходу до вирішення не лише економічних та соціальних, а й екологічних проблем. Вирішення останніх нерозривно пов'язане з чітким визначенням місця і ролі економічних інтересів людей та ï синхронізацією 3 екологічними нормативами. Політика сталого розвитку повинна бути чітко спрямована на неухильне забезпечення тісного зв'язку економіки з екологічними проблемами.

Нинішній стан довкілля, як підкреслюється в Основних напрямках державної політики України в галузі охорони природного середовища, використання природних ресурсів i забезпечення екологічної безпеки можна характеризувати як кризовий.

Важливим напрямом підвищення ефективності управлінської діяльності у сфері природокористування i охорони навколишнього середовища $\epsilon$ узгодження економічних та екологічних інтересів підприємств, установ, організацій, суспільства в цілому та окремих індивідів. Відображаючи економічні та екологічні інтереси суспільства держава повинна створювати необхідні і оптимальні умови для поєднання економічного розвитку 3 природокористуванням та охороною довкілля. Це можливо лише шляхом комбінації заходів адміністративноправового впливу на природокористувачів та заходів економічного регулювання на природокористування i охорони навколишнього природного середовища.

Донедавна державне управління охорони довкіллям і природокористуванням здійснювалося адміністративними методами, які посідали домінуюче місце i відігравали визначальну роль у природоохоронному механізмі країни. Реалізація цих методів була перш за все пов'язана із створенням відповідних адміністративних структур, які були наділені комплексом повноважень щодо застосування заходів прямого примусу до діяльності, яка пов'язана 3 впливом на навколишне середовище та використанням природних ресурсів шляхом встановлення екологічних обмежень щодо виробничої діяльності, а саме затвердження нормативів допустимих викидів, скидів забруднюючих речовин, правил складування відходів виробництва, надання дозволів на спеціальне природокористування, обмеження чи призупинення виробничої діяльності, що становила загрозу здоров'ю людей, довкіллю, тощо [2].

$$
\text { Такі методи в умовах }
$$

адміністративно-командної системи управління були об'єктивно необхідним заходом впливу на екологічну мотивацію поведінки суб'єктів правоохоронних відносин. Але ж відсутність економічних важелів i економічного стимулювання призводила до незацікавленості в забезпеченні комплексного і раціонального використання природних ресурсів, попередженні забруднення i належній охороні навколишнього середовища. Тоді було здійснено перехід від переважно адміністративних до економічних методів управління природоохоронною діяльністю. Але практика підтвердила необхідність тісного поєднання адміністративних i економічних методів у цій сфері.

На сьогоднішній день засади економічного механізму забезпечення охорони навколишнього природного середовища зафіксовані в X розділі Закону України «Про охорону навколишнього середовища». Перевага надається екологічному нормуванню, лімітуванню, ліцензуванню, експертизі, контролю, тобто забезпеченню виконання відповідних стандартів i норм примусом із боку держави, що не спонукає підприємства, установи й організації до здійснення природоохоронної діяльності [1].

На сучасному етапі розвитку економіки можна виділити такі елементи

Вісник економіки транспорту і промисловості № 60, 2017 
економічного механізму регулювання природоохоронної діяльності:

- плата за природокористування;

- система

стимулювання

діяльності;

- плата

за

природоохоронної

навколиниього середовища та розміщен відходів;

ресурсів;

- створення ринку природних

- удосконалення

системи

ціноутворення 3 урахуванням екологічних факторів, особливо на продукцію природо експлуатуючих галузей народного господарства;

- створення екологічних фондів;

- екологічне програмування;

- торгівля ліцензіями;

- платежі за заставу;

- екологічне страхування.

Основною метою економічних механізмів природокористування та природоохоронної діяльності є:

- стимулювання

шляхом

впровадження еколого-економічних інструментів природокористувачів до зменшення шкідливого впливу на довкілля, раціонального та ощадливого використання природних ресурсів і зменшення енерго- i ресурсомісткості одиниці продукції;

- створення за рахунок коштів, отриманих від екологічних зборів i платежів, незалежного від державного та місцевих бюджетів джерела фінансування природоохоронних заходів і робіт.

Економічний механізм регулювання природокористування в Україні грунтується на концепції платності. Система платежів за користування природними ресурсами включає в себе не тільки способи визначення розмірів плати, а також механізми іiі встановлення, вилучення й використання.

Розрізняють шість видів платежів за ресурсами:

- платежі за право користування природними ресурсами;
- плата за відтворення та охорону природних ресурсів;

- рентні платежі за експлуатацію кращих природних ресурсів за якістю чи за місцем їх розташування стосовно ринку;

- штрафні платежі за понаднормове використання природних ресурсів;

- компенсаційні платежі за вибуття природних ресурсів із цільового використання або погіршення їхньої якості, спричинене діяльністю цих підприємств;

- плата підприємств за

використання середовища для розміщення відходів виробництва.

Плата за користування природними ресурсами повинна залежити від умов, які визначають попит і пропозицію на цей ресурс на конкретній території, і вилучатися у вигляді конкретного податку (збору) або плати за ліцензію, що дає таке право, чи у вигляді орендної плати.

Використання природних ресурсів в Україні здійснюється в порядку загального та спеціального використання. Законодавством України громадянам гарантується право загального використання природних ресурсів для задоволення життєво необхідних потреб (естетичних, оздоровчих, рекреаційних, матеріальних) безоплатно, без закріплення цих ресурсів за окремими особами й надання відповідних дозволів.

У порядку спеціального використання природних ресурсів громадянам, підприємствам, установам, організаціям надаються у володіння, користування або оренду природні ресурси на підставі спеціальних дозволів у формі ліцензій, зареєстрованих в установленому порядку за плату для здійснення виробничої діяльності, а у випадках, передбачених законодавством - на пільгових умовах. Ліцензія $\epsilon$ документом, який засвідчує право ¥iі власника на використання природних ресурсів у визначених межах, 3 відповідно вказаною метою протягом встановленого строку під час додержання ним заздалегідь визначених вимог та умов.

Вісник економіки транспорту і промисловості № 60, 2017 
Недосконалою є система штрафних санкцій, оскільки штраф - це покарання винного, а не відшкодування збитків, завданих природному середовищу. Тобто, штраф платиться один раз, а порушення навколишнього природного середовища тривають. Плата за відтворення (компенсацію) природного ресурсу повинна залежати від середовища утворюючої ролі й визначатися затратами на підтримання заданого рівня якості навколишнього природного середовища 3 урахуванням встановлених для даного регіону пріоритетів розвитку та фактора часу.

Платежі на відтворення й охорону природних ресурсів - це компенсація затрат природних ресурсів (вилучення) у процесі виробництва.

В Україні фінансування заходів щодо охорони навколишнього природного середовища здійснюється за рахунок:

- державного бюджету України та місцевих бюджетів;

- коштів підприємств, установ та організацій;

- позабюджетних фондів охорони навколишнього природного середовища; коштів.

- добровільних внесків та інших

Нормативи плати за використання природних ресурсів визначаються 3 урахуванням їхнього географічного положення, поширення, якості, можливості відтворення, доступності, комплексності, продуктивності, можливості утилізації, відходів, умов переробки.

Економічні оцінки природних ресурсів і плата за природні ресурси часто збігаються, але це не означає, що вони $є$ тотожними за економічним змістом. Показники економічної оцінки мають бути порівняльними, тобто давати змогу порівнювати різні джерела однойменних ресурсів і варіанти їх використання.

Основними елементами фінансового механізму екологічного призначення в розвинених країнах виступають, як правило, урядові субсидії, позики і пільгові позики, залогові вкладення; прискорена амортизація; екологічні та екологоорієнтовані податки (в тому числі транспортні та енергетичні); платежі i штрафи за скиди і викиди забруднюючих речовин; платежі за розміщення твердих відходів; адміністративні платежі (за видачу ліцензій, формування систем компенсації або екологічних квот i iн.); збори екологічного характеру (на екологічно «брудну» продукцію і небезпечні відходи); платежі за використання природних ресурсів; різного роду податкові пільги, що стимулюють зниження негативного впливу на навколишнє середовище, в тому числі за допомогою впровадження екологічних інновацій та інвестування в екологічно безпечні i ресурсозберігаючі технології; додатковий податок 3 прибутку підприємств, що випускають екологічно шкідливу продукцію або застосовують екологічно небезпечні технологіі; екологічне страхування (на випадок непередбачених екологічних ситуацій як антропогенного, так i природного характеру); пряма торгівля допусками на забруднення середовища; державні інвестиції на природоохоронні заходи та державні закупівлі товарів природоохоронного призначення; дотації від держави і інші інструменти. В останні роки велика увага приділяється таким економічним інструментам екологічної політики, які стимулюють прискорений розвиток інноваційних маловідходних i ресурсозберігаючих технологій, широке залучення альтернативних та відновлюваних джерел електроенергії, створення умов для впровадження електротранспорту і т. п.

Досвід країн 3 розвиненою екологічною політикою також свідчить про те, що серед методів державної екологічної політики все більші переваги віддаються не тільки обмежувальним заходам і покаранню винних, скільки винагороді зусиль тих природокористувачів, чия економічна поведінка сприяє поліпшенню стану навколишнього середовища. Іншими словами, відбувається зсув від

Вісник економіки транспорту і промисловості № 60, 2017 
використання адміністративних важелів управління до більш широкого застосування економічних (в тому числі фінансових) методів регулювання в екологічній сфері [4].

Головна відмінність вітчизняної системи екологічного оподаткування від європейської полягає в тому, що механізми iï реалізації є неефективними, оскільки не створюють в економічних агентів реальних стимулів для природоохоронних дій. Економічний механізм природокористування має переважно фіскальну спрямованість, виступає засобом нагромадження фінансових ресурсів у владних структурах. Тобто, держава переважно декларативно виступає за збереження довкілля, а насправді є таким суб'єктом природокористування, якому вигідне використання ресурсів, оскільки за рахунок зборів за використання природних ресурсів поповнюються бюджетні кошти [8].

Зважаючи на еколого-економічну ситуацію в Україні та досвід організації природоохоронної діяльності в країнах членах $\mathrm{CC}$, на сьогодні екологічні фактори включені у систему пріоритетів стратегічної економічної політики. Найбільш визначальними пріоритетами $є$ :

- удосконалення фіскального регулювання природокористування через упровадження перспективних форм i методів нарахування (адміністрування) ресурсних платежів та екологічних зборів;

- розбудова фінансово-кредитної та банківської систем, що матимуть природноресурсну та екологічну спрямованість і прискорюватимуть інноваційне оновлення засобів виробництва в природно-ресурсній cфepi;

-широкомасштабне впровадження у практику господарської діяльності елементів екологічного менеджменту 3 метою постового входження вітчизняних підприємств-природокористувачів

$\mathrm{y}$ систему екологічних стандартів, що функціонує в країнах розвиненого капіталізму.
Таким чином, поєднання правового і економічного механізмів регулювання природокористування $€$ одним зі стратегічних напрямів екологічної політики держави, що дозволить забезпечити раціональне використання природних ресурсів та охорону довкілля та формування стабільних джерел фінансування природоохоронних заходів. Тож, подальших досліджень потребують аналіз зарубіжного досвіду та тісне співробітництво нашої країни 3 провідними країнами світу у сфері природокористування.

Висновок. Україна має будувати свою економічну систему природокористування але адекватно до цілей, вимог, правил, принципів, стандартів екологічної політики ЄС. Стрижнем екологічної політики України має бути стимулювання природоохоронної діяльності, яке грунтується на існуючій методологічній базі, апробованій вітчизняною практикою, а також враховує досягнення інших країн у вирішенні екологічних проблем.

Удосконалення діючого економічного механізму природокористування і природоохоронної діяльності та формування стабільних джерел фінансування природоохоронних заходів в умовах переходу до ринкових відносин має стати органічною складовою системи управління i регулювання економіки, стимулювати охорону i відтворення природно-ресурсного потенціалу країни шляхом створення відповідних економічних умов.

\section{ПЕРЕЛІК ВИКОРИСТАНИХ ДЖЕРЕЛ}

1. Про Основні засади (стратегію) державної екологічної політики України на період до 2020 року: Закон України від 21 грудня 2010 року № 2818-V1// Відомості Верховної Ради України. 2011. -№ 26. -1284 c.- Ст. 218.

2. Про Стратегію сталого розвитку «Україна - 2020»: Указ Президента України 
від 12.01.2015 №5 /2015// Урядовий кур’єр. -2015 . -15 січня. - № 6.

3. Офіційний сайт Міністерства екології та природних ресурсів України [Електронний ресурс]. - Режим доступу: https:// menr.gov.ua/files/docs/Proekt/_ proekt_11_09_2017.pdf

4. Веклич О.О., Бугас В.В. Потрібен євроремонт економічного механізму екологічного регулювання // О.О.Веклич, В.В. Бугас // Вісник НАН України. - 2006. №3. - C. 49-57

5. Васюта О.А. Проблеми екологічної стратегії України в контексті глобального виміру / О.А.Васюта. Тернопіль: «Гал-Друк», 2001. - С. 227- 228.

6. Хвесик М.А., Горбач Л.М., Кулаковський Ю.П. Економіко-правове регулювання природокористування / М.А.Хвесик, Л.М.Горбач, Ю.П.Кулаковський. - К.: Кондор, 2004. $479 \mathrm{c}$.

7. Коржнев М.М. Економіка природокористування // М.М.Коржнев. К.: Видавництво КНУ. - 99с.

8. Офіційний сайт Представництва Європейського Союзу в Україні [Електронний ресурс]. - Режим доступу: https://eeas.europa.eu/delegations/ukraine_uk

\title{
УДК 331.108.2
}

\section{УПРАВЛІННЯ РОЗВИТКОМ КАДРОВОГО ПОТЕНЦАЛУ ПІДПРИЕМСТВ В СУЧАСНИХ УМОВАХ}

\author{
Корінь М.В., к.е.н, доцент, \\ Шевченко О.О., магістр, \\ Шовкопляс О.О., магістр (УкрДУЗТ)
}

В статті досліджено підходи до визначення сутності поняття «кадровий потенціал», щуо дозволило зробити узагальнюючий висновок про його особливості і роль у забезпеченні ефективності роботи підприємств. Розкрито традиційні елементи управління персоналом та визначено фактори і передумови трансформаціі управління розвитком кадрового потенціалу вітчизняних підприємств в сучасних умовах. Запропоновано основні напрямки удосконалення кадрової роботи підприємств на оперативному та стратегічному рівнях.

Ключові слова: кадровий потенціал, управління, розвиток, стратегічний підхід, чинники та передумови удосконалення управління.

\section{УПРАВЛЕНИЕ РАЗВИТИЕМ КАДРОВОГО ПОТЕНЦИАЛА ПРЕДПРИЯТИЙ В СОВРЕМЕННЫХ УСЛОВИЯХ}

\author{
Коринь М.В., к.э.н, доцент, \\ Шевченко Е.А., магистр, \\ Шовкопляс А.А., магистр (УкрГУЖТ)
}

В статье исследованы подходы к определению сущзности понятия «кадровый потенциал», что позволило сделать обобщающий вывод о его специфике и роли в

(C) Корінь M.B., Шевченко О.О., Шовкопляс O.O.
Вісник економіки транспорту і промисловості № 60, 2017 238 